\title{
Chapter 3 \\ Context-Based Qualitative Research and Multi-sited Migration Studies in Europe
}

\author{
Russell King
}

\subsection{Introduction}

As a phenomenon which considers human mobility between places, across spaces, and through time, migration is inevitably context-dependent. The two basic contexts which frame migration (and other forms of human mobility) are the geographical/ spatial context and the historical/temporal one. Both the geographical and temporal contexts are multiple, given the essential character of migration as a form of mobility or 'moving' process. The diversity of migration trajectories - no longer limited to the bipolar origin and destination - opens up new sites, mobile routes and research methods for migration research, reflecting George Marcus's (1995) encouragement of anthropological researchers to 'follow the people'. Especially in Europe, with its complex interlocking regime of open, closed and differently permeable borders, migrants follow multiple and often unpredictable spatio-temporal trajectories, including circular, seasonal and pendular migration, return mobilities, and onward or stepwise migration, to name but a few. Research studies on European (and global) migration patterns therefore need to be flexible and responsive to a phenomenon which is constantly changing. Whilst some historical certainties persist - such as the dictum that migrants tend to move from poor to wealthy countries - the modalities and routes through which this fundamental rationale of self-improvement is realised are constantly evolving and switching. A multi-sited approach, although not always necessary or achievable, is nevertheless increasingly appropriate to fully appreciate the ongoing complexity of migratory phenomena.

The broad and interdisciplinary field of migration studies encompasses two distinctive stages: the initial dynamics of migration, based on the determinants, processes and patterns of actual movement; and the ensuing settlement and 'integration'

\footnotetext{
R. King $(\bowtie)$

University of Sussex, Brighton, UK

e-mail: R.King@sussex.ac.uk
} 
phase, which focuses on how migrants are incorporated, often problematically, into receiving societies (Castles and Miller 2009, p. 20). This distinction has been intrinsic to the foundation and on-going research of the IMISCOE network, whose very title distinguishes between 'migration' and 'integration and social cohesion' and whose first major collective output, entitled The Dynamics of International Migration and Settlement in Europe (Penninx et al. 2006), was predicated on that very structural division. This two-stage conceptual frame remains heuristically useful but, as Castles and Miller (2009, p. 20) go on to point out, is also artificial and hampers a complete understanding of what they regard as the 'overall migratory process'. Nevertheless, in this chapter we are mainly, if not quite exclusively, concerned with the initial phase of the migratory process, and less with the longer-term integration and accommodation of migrants.

This chapter is in three parts. The first expands on the overriding importance of context when studying migration, based on a multi-layered typology of contextual settings. The second part stresses the value of multi-sited research in migration studies and takes its inspiration from the landmark paper on multi-sited ethnography by Marcus (1995). In the third section, I illustrate the value of contextualised, multi-sited research by taking examples from my own research on post-1990 Albanian migration to Europe.

\subsection{Context is Crucial}

The importance of context for the study of migration cannot be denied: there is the sending-society context, the receiving-society context, as well as the contextual settings of routes traversed and places and spaces passed through. Context becomes increasingly important as migratory phenomena become more diversified, and as the statistical grasp over migration flows and stocks becomes less secure. Within the European context, this decreasing ability to accurately quantify migration is related to three things: freedom of movement within the EU and European Economic Area; the movement of irregular migrants from outside the EU; and the blurring of the distinction between migration and other forms of mobility such as seasonal migration, long-stay tourism, student exchanges, etc. Whilst some elements of context can be quantified (demographic and socio-economic variables, citizenship rights, legal status, etc.), the complex nature of these factors as potential drivers of migration, and their interaction with each other, can only be appreciated via a more qualitative approach rooted in specific socio-economic, political, cultural and spatial settings.

Further complications arise, especially in the current European migration scenario, when we realise that the origin-destination-transit triad only captures part of the spatio-temporal complexity of European migration nowadays. Many countries are simultaneously experiencing immigration, emigration, return migration (both of their own emigrants and of the immigrants hosted), and transit migration - let alone the interface with internal migration, both of 'native' populations and of immigrants 
who move within their host country (King and Skeldon 2010). This 'complexification' of the migration landscape is further enhanced by different temporal patterns of movement (permanent, temporary, circular, etc.), migrant typologies (economic migration, family reunion, refugees/asylum-seekers, students, retirement and lifestyle migrants), legal status (naturalised, long-stay denizens, short-stay permitholders, undocumented/irregular, etc.), position in the labour market (low, medium or high-skilled), age, gender, ethnicity and so on (Zapata Barrero and Yalaz 2018). An exemplary illustration of the simultaneous and interlocking dynamics of several types of migration has been the case of Greece, especially over the past decade of financial crisis. As Pratsinakis et al. (2017) have shown, Greece's earlier typically Southern European transition from mass emigration up to the mid-1970s to largescale immigration after 1990 has been succeeded and overlain by a whole slew of new migratory forms - emigration of mainly young, educated Greeks since 2008, return or onward migration of a significant share of the main immigrant nationality (Albanians) triggered by the crisis, arrival of refugees during 2015-2016, and finally a reshaping of internal migration dynamics from rural-urban migration to counter-urbanisation.

\subsubsection{Spatial and Political Contexts}

Taking on board the increasing diversity, complexity, and 'mixed flows' nature of contemporary European migration, let us now try to be more systematic in categorising context. The first contextual level to note is the macro-spatial geopolitical context. Europe is a very different, and more complex, theatre for migration than North America, especially the United States, where a lot of migration theory and survey methodology has been hatched (see Brettell and Hollifield 2015). In contrast to the unified framework for immigration in the US, Europe has both the overarching regulatory framework of the Single Market and Free Movement within the Schengen area, and the diverse political frameworks of around 40 countries, both inside and outside the EU. Amongst the features that give Europe a distinctive contextual role in the study of international migration are its complex history of nationmaking; its colonial past and the imprint this has had on migration flows into former colonial metropoles such as France, the UK, the Netherlands and Portugal; its varied citizenship regimes (ius sanguinis, ius soli, ius domicilii, etc.) and integration policies (exclusion vs. integration vs. multiculturalism); its mosaic of languages, cultures and religions; and, last but not least, its geographical proximity to "hot spots' of migration-generating conflict in Africa and the Middle East.

The spatial context of migration expresses itself at multiple levels and in several forms; from the European/EU continental scale to national political and integration regimes, and to regions, cities, neighbourhoods and villages. The national, regional or city-level context of statistical records and quantitative surveys often overlooks the local socio-geographical contexts - typically the urban neighbourhood where migrants settle, and the rural, village context from which they leave, and maybe 
return to. In reality, there is a multi-layered scale hierarchy which builds on the now well-established transnational view of migration. In its initial formulation, 'transnationalism' referred to a process whereby 'transmigrants' inhabited social fields ('transnational social spaces'; Faist 2000) spanning their country of origin and that (or those) of their settlement abroad. They generated 'regular and sustained' crossborder ties of economic, social, political and cultural relations (Glick Schiller et al. 1992). The discovery of this 'new fact' (was it really new? - some said not; Foner 1997; Waldinger and FitzGerald 2004) that transmigrants live in complex borderspanning systems, maintaining activities, statuses and identities which were no longer 'contained' within a single nation-state, led to an important critique of prior research as being too wedded to what Wimmer and Glick Schiller (2002) called 'methodological nationalism'.

The context-changing transnational paradigm has reshaped the way migration research, especially in Europe and North America, is carried out, including an obvious predilection for multi-sited endeavours, a theme I pick up later. Meantime, Hoerder (2012) has expanded the territorial-scale aspects of the transnational approach to migration by discussing the spatial hierarchy of multi-layered scales that pass from the global to the European, then to the national, and down to the transregional, translocal and the more a-spatial transcultural. These sub-national migrant social fields may also be scale-differentiated in another way: for instance, within Europe, between near and distantly located spaces (southern Albania and northern Greece is a contiguous transnational and transregional migratory space, whereas central Turkey to Stuttgart is a much more distant bipolar space), or beyond the borders of Europe, as with migrants originating in specific districts of countries in Latin America, Africa or Asia.

Above all, it is the important translocal contexts that shape the social realities of migrants' everyday lives, rather than a deterritorialised transnationalism (Brickell and Datta 2011). Embedded within these translocal social fields are the social and kinship networks that are the lifeworlds of migrants and their families and communities. At these (trans)local levels other micro- and meso-scale contexts come into play, which include the family context (does the migrant migrate alone, or with other family members?), age and gender selectivities (from many migrant origins, it is mainly young men who leave, but in some migration flows, it is mainly women who move), socio-occupational status (lower vs. higher skilled, employed vs. unemployed), educational qualifications (does migration remove the brightest and best'?), ethnicity (are migrants a discriminated minority in their country of origin?), and so on.

When aggregated up to a larger scale, these contextual variables can express themselves as important national-level migratory characteristics and processes such as the brain drain of the highly educated, or an unbalanced loss of youthful labour - which can distort the demographic shape and socio-economic status of the remaining population. Similar, though often inverse in nature, impacts are likely to be made in the contextual setting of the migrants' destination, as well as on the spaces and places passed through in the case of transit migration. 
Another set of contextual issues is evident in the political domain. Are migrants persecuted refugees, or discriminated minorities, or political dissidents? Similarly, does the political context of the receiving society function as an attractive factor for migrants, or are the political structures and allied obstacles to various kinds of citizenship a problem for migrants that has to be accepted and/or struggled against? Finally, under spatialised geopolitical contexts, how do borders present themselves as barriers or sieves for migration, providing their own linear spatial contexts for the channelling or blocking of migratory movements?

\subsubsection{Temporal and Historical Contexts}

Alongside these multi-scale spatial contexts for framing our understanding of migration are similarly multi-level temporal contexts, which can be systematised as follows, following Fielding (1993). The first temporal context is related to the business cycle - the conjunctural alternation between economic growth and stagnation or decline that seems to be inherent in capitalist economies such as those in (Western) Europe. Migration (more specifically immigration to the growth economies) increases during the years of boom, and then falls (or net immigration turns to net emigration) during the trough years of the economic cycle. The immediate post-war decades of European labour migration illustrate this pattern very well: 'mass migration' (King 1993) during the 'long boom' of the fordist years of industrial development (circa 1950-1973), followed by sharp reductions and even reversals in migration (net return migration) during the subsequent oil crisis. The most recent economic crisis, driven this time by financial collapse and mismanagement in the late 2000s and early 2010s, has also seen a tangible impact on migration flows, this time outwards from those countries most severely hit by the euro-crisis such as Greece, Spain and Portugal.

At a second temporal level are what Fielding calls 'restructuring' societal and economic changes which have longer-term impacts on migration (1993, pp. 9-14). Key here is the reorganisation of the production system driven by the new international division of labour (Fröbel et al. 1980), producing a new international geography of labour power and capital distribution. Several processes impacting migration have been at work here. The post-fordist break-up of large industries created a new geography of 'diffuse industrialisation' based on subcontracting and regional sectorial specialisation in 'intermediate' locations in Europe based on flexible supplies of labour, including new waves of migrants. This was seen most clearly in Italy where the industrial triangle of Milan-Turin-Genoa in North-West Italy gave way to a new economic dynamism centred on smaller-scale industries in regions such as Veneto, Emilia-Romagna and Tuscany in North-East and Central Italy (King 1985). Meanwhile, at a global scale, the concentration of capital in metropolitan centres such as London, New York and Tokyo, and the redistribution of labour-intensive manufacturing to the developing world reworked the global division of labour, the main results of which were the growth of high-skilled migration towards the 
metropolitan cores of the fast-changing global economy, and the parallel rise in lowskill migrant service labour to support the lifestyles of what Sklair (2001) has called the 'transnational capitalist class'. For the evolution of migration patterns within Europe, two further restructuring events of keystone importance - this time geopolitical - were the removal of the migration barrier of the Iron Curtain in 1989-1990, and the progressive eastern enlargement of the EU since 2004; both of which have revolutionised migration dynamics within Europe in recent decades. A third and more recent significant event, the Brexit referendum in June 2016, may provide a new context for migration flows into the UK, especially from EU countries. EU immigration was at the heart of the public and media debate surrounding Brexit, but it remains to be seen what the concrete impact on migration trends will be.

Fielding is less clear about the nature of his third temporal migration context of 'deep structural' processes which, in his words (1993, p. 15), 'are so deep-rooted that for all intents and purposes they are unchanging from one decade to another'. He points to the on-going migrations 'which reflect the basic economic inequalities of the world in which we live', and especially 'the massive differences in life chances between Western European countries and those of the Third World' (1993, p. 15). Actually, within these deep global-scale migration structures, there are changes afoot, of which two can be highlighted here - the rise of China and India to global economic power status, and the impact of climate change on migration.

This threefold typology of Fielding is heuristically attractive but it does not exhaust the range of temporal influences over migration (Cwerner 2001). Other temporal contexts, of an even shorter duration than the economic cycle, result from geopolitical events, civil wars, and natural (or non-natural) disasters, the most recent being the Syrian refugee crisis, whose effects massively impacted on Europe throughout 2015 and early 2016 (King and Collyer 2016). Yet other temporal contexts relate to life-course and the spikes in migration propensity that result from the transition from one life-stage to another. Typical examples would be the transition from the end of full-time education to the search for employment; or, at the other end of the life-course, at or around retirement.

\subsection{Migration Research Should Be Multi-sited}

Along with mixed-methods, multi-sited fieldwork seems nowadays to have become de rigeur in doctoral theses on migration, especially those studies which are explicitly comparative in their focus - a point I shall return to later. This holds especially for empirical studies carried out within the disciplinary frames of human geography, sociology and anthropology, as well as those with an inter- or multi-disciplinary optic. That said, it is not compulsory that all migration research has to be multisited: excellent research can be done in one place. Examples of such single-sited research would be those carried out at the migrants' place of origin - for instance, studies of the factors leading to migration, or on the impact of remittances, or of return migration; the migrants' place of destination - for instance, studies of 
integration, ethnic community formation or residential segregation; or at a place of transit such as a border site or a refugee camp, or a city of transit such as Istanbul where migrants aim to pass through but often stay longer-term.

However, it does seem that, given the very nature of migration as a human process that traverses spaces and connects two or more places, multi-sitedness in research design is either desirable or inevitable, a point strongly made by Boccagni and Schrooten (2018) in their contribution to this volume. The 'push' for multi-sited research is not driven just by pure methodological fashion, but rather can be related to important conceptual advances in how (international) migration is theorised and studied. Migration is essentially about border-crossing, transnationalism (and transregionalism, translocalism, etc.) and a range of multi-sited and multi-path mobilities. Phenomena such as the globalisation of economies, cultures and communications, and above all the globalisation of international migration (Castles and Miller 2009, p. 10), set the scene for the well-known critique of methodological nationalism (Wimmer and Glick Schiller 2002) - an epistemological thrust that has guided much social science thinking over the past two decades, including new fieldbased methods based on a variety of 'non-national' units of analysis such as cities (Glick Schiller and Çaglar 2009), 'translocalities' (Anthias 2009; Brickell and Datta 2011), migrant social networks and other multi-sited fields that span borders (Amelina et al. 2012, pp. 4-9).

In reaction to the critique of methodological nationalism and its associated 'container thinking', Amelina and Faist (2012) elaborate a new 'methodological transnationalism' (pace Khagram and Levitt 2008), encompassing a range of perspectives and research methods, chief amongst which are multi-sited research designs, which also include so-called mobile methods, which will be detailed later. Such methods recognise the simultaneity of the transnational practices of individuals and migrantrelated organisations and institutions, including the transactions and relations between those who have migrated and those who have stayed in place (Levitt and Glick Schiller 2004).

A further powerful justification for multi-sited research designs comes from the increasing importance of comparative studies of migration in exploring both the contrasts and complexities of social, spatial and historical contextualisation, and the need to look for meaningful similarities and generalisations (FitzGerald 2012). Such comparisons can include, but should go beyond, cross-sectional or 'horizontal' studies of migrants in different host-society contexts - a comparative strategy that leans heavily on assimilation and integration frameworks. Rather, multi-sited comparative research should also extend to comparing both the contexts of departure and destination, and the too-rare comparison of international and internal migration flows and outcomes (King and Skeldon 2010). Also important, when analysing what is allegedly distinctive about migrants' characteristics and behaviour, are comparisons between migrants and the control group of non-migrants - nonmigrants in the origin country (bearing in mind that they, too, might become migrants in the future), and in the receiving society. That being said, it is important to clarify that the relationship between multi-sited and comparative research is not inevitably symbiotic: not all multi-sited research is comparative, and not all 
comparative research is multi-sited. As an epistemological issue, comparison in migration studies may be necessary but this approach also brings its own perils, as two other chapters in this book spell out (Iosifides 2018; Jacobs 2018).

\subsubsection{Spatial Designs for Multi-sited Research}

Several spatial research design scenarios suggest themselves for multi-sited (and usually comparative) research.

- The origin-departure nature of many migration systems which are spatially bilocal opens up the possibility of field investigations at both 'ends' of the migration trajectory - 'here' and 'there'. This also facilitates studies of return migration, which 'reverses' the origin-destination matrix. For a pioneering set of anthropological studies which operationalised the two-ended nature of migration see James L. Watson's edited book Between Two Cultures (1977), or Robert C. Smith's Mexican New York (2006) for a recent classic. Often the perspectives of the sending and receiving context of migration, and perhaps later of return, are quite different, also in terms of how migrants, non-migrants and returnees interpret and narrate the effects of migration on themselves and the wider communities of which they are part. A variation of this multi-sited spatial design is the 'village-outward' approach of some studies of chain migration (e.g. Baily 1992).

- The more extensive study of migrants in different places is more challenging for a single researcher, but actually increasingly common in ambitious doctoral and post-doctoral research - a good example being Vathi's (2015) study of Albanian migrants and their children in London, Florence and Thessaloniki. Vathi's study was part of the ambitiously comparative TIES project on 'The Integration of the European Second Generation', which has generated a rich vein of research results on the education, employment, transnational and identificatory experiences of second-generation Turks, Moroccans and 'ex-Yugoslavs' in a variety of European cities and countries (see e.g. Crul et al. 2012).

- Other matrices of multi-sited research on migration reflect the networks and circuits that migrants form and become part of. Complex assemblages of sites and trajectories are created by transnationalism, diasporas, onward migration etc., often shaped by colonialism or 'post-imperial formations' (Hansen 2014), trade and virtual social networks, so that the causal processes observable at each site are not independent of each other (FitzGerald 2012, p. 1726). Cases of multisited fieldwork in a transnational and/or diasporic context are also legion: one particularly apposite example is Falzon's (2005) research on the widely-spread Sindhi trading diaspora. 


\subsubsection{Marcusian Multi-sited Ethnography}

The methodological literature on multi-sited research inevitably pays tribute to George Marcus' (1995) clarion call in favour of multi-sited ethnography as a means to bridge the dichotomy between local realities and larger-scale social orders all the way up to the capitalist world system. Marcus' key point was simply that there are many social phenomena that cannot be fully accounted for by focusing on a single site, and which therefore benefit from field sojourns in more than one place. According to Falzon (2009, p. 2), his approach 'fired the spatial imagination of a generation of social scientists'. Marcus' landmark paper was primarily addressed to anthropologists, and actually says rather little about migration. However, he was at pains to stress the relevance and growth of new spheres of interdisciplinary research - he specifically mentioned cultural studies and media studies, and we might easily add migration studies to this, following the lead of Borkert (2018) in this volume.

Marcus proposed moving away from the conventional single site of traditional 'Malinowskian' anthropological enquiry - typically a remote community where the field anthropologist immerses him/herself for at least a year - to multiple sites related to complex macro-processes such as globalisation, new global social orders, transnationalism and human movement. Above all he was concerned to challenge and link together what he called (1995, p. 95) 'cross-cutting dichotomies' such as the local and the global, or lifeworld and system, resulting therefore in ethnographies which are, to quote the title of his paper, both 'in' and 'of' the global system. Here is his most cogent definition:

Multi-sited research is designed around chains, paths, threads, conjunctions, and juxtapostions of locations in which the ethnographer establishes some kind of literal, physical presence, with an explicit, posited logic of association or connection among sites that in fact defines the argument of ethnography (1995, p. 105).

His rallying cry for multi-sited ethnography reflected (but also pioneered) shifts in the epistemology of anthropology away from classical studies of 'peasant' or 'traditional' rural societies with their assumed essence of 'subaltern' communities, towards new ethnographies embracing interlocking nodes of cities, markets, states, the media, industries, organisations, elites, academia, etc. - what has come to be known as 'studying up' (Marcus 1995, p. 101, quoting Nader 1969). Moreover, in the contemporary world of social science, 'the object of study is inherently mobile and multiply situated, so any ethnography of such a subject will have a comparative dimension that is integral to it, in the form of juxtapositions of phenomena that conventionally have appeared to be (or conceptually have been kept) "worlds apart"” (Marcus 1995, p. 102). It is not hard to see in this quote an articulate prefiguring of the 'mobilities paradigm' which has helped to re-frame our understanding of the dynamics of European migration in the last decade or so (see Cresswell 2006; Urry 2007). 


\subsubsection{Critiques of Multi-sited Ethnography}

The trend towards multi-sited ethnography has not gone unchallenged. Some of the critiques have been trenchant (e.g. Candea 2007; Hage 2005); others more balanced, combining prosecution and defence (e.g. Coleman and von Hellermann 2011; Falzon 2009; FitzGerald 2012); and Marcus himself has responded to the critiques and reappraised his original 1995 paper (Marcus 2007, 2011). Amongst the critiques, the most severe is the provocation by Hage (2005), who sees multi-sited ethnography as little more than a buzzword, a reflection of 'delusions of innovativeness'. Hage then concludes: 'I simply do not think there can be such a thing as multi-sited ethnography' (2005, p. 465).

The main critique is to question the depth and quality of fieldwork spread across several sites. Given the well-known challenges of doing in-depth fieldwork in one site, how can the same long-matured insights be developed when the field effort is dispersed and therefore diluted? Defendants of the so-called 'thick description' achieved through 'deep ethnography' in order to understand the 'ways of the people' - methodological principles enunciated by generations of anthropologists (for instance, Geertz 1973; Clifford 1997) - are sceptical about the sacrificing of detailed local knowledge implied by spreading oneself across several field sites. The purists are dismissive of 'itinerant ethnographers' whom they see as little more than travelling journalists or curious tourists. As Burawoy (2003, p. 673) put it: 'Bouncing from site to site, anthropologists easily substitute anecdotes and vignettes for serious field work'. But does a plurality of sites automatically mean dilution of research findings and their associated depth of insight? My answer, from a migration studies perspective, is a resounding 'No', for the following reasons.

First, the view of the single site as, indeed, a single site is itself flawed. The 'traditional' ethnography of a village is actually composed of multi-sited research, as the field-worker observes and encounters people in several settings - their homes, workplaces (out in the fields), their places of worship, their sites of relaxation (bars, cafés, the village square) or in community gatherings (the town hall, community centre, schools, etc.). Falzon (2009, p. 8) approvingly quotes Boissevain's approach to his fieldwork in A Village in Malta (1980, p. 116), where he lists the significant places and spaces in the village where he habitually stopped for information and conversation - the church, the main square, the priest's house, the bus stop, the barber shop etc.

Second, there is no reason, in principle, why in-depth fieldwork cannot be accomplished in more than one site. If 6 months is regarded as the minimum to achieve in-depth understanding, then two or three sites can reasonably be accommodated in a 3- or 4-year research project; allowing time for the integrated and comparative analysis of the material collected.

Third, the critique falls if the objects of study are themselves mobile - as migrants and other mobile people (travellers, tourists, adventurers, etc.) obviously are. This opens up a new methodological scenario - mobile ethnography. Field research is no longer confined to fixed points such as villages, towns, workplaces, etc., but is done 
'on the move', on buses, trains, cars, airplanes, or at staging posts such as airports, bus stations, border crossing points, etc. The notion of 'fieldwork as travel practice' ... 'represents the way [mobile] people themselves experience the world' (Falzon 2009, p. 9, emphasis in the original). The richness of 'mobile methods' has been explored by Büscher and Urry (2009; also Büscher et al. 2010), which involves collecting ethnographic and other data by observing people's spatial movements, 'shadowing' them or 'lurking' around those on the move.

Mobile methods have two further advantages. First, they enable the researcher to 'fix' migration and mobility in space and time by observing and experiencing the lived spatio-temporal rhythms of movement, delay, settlement, return, etc. (King and Lulle 2015; Meeus 2012). Second, the method acknowledges the dialectical relationship between mobility and immobility, offering chances to analyse both within a transnational or translocal perspective (Amelina and Faist 2012).

Another challenge to the use and interpretation of multi-sited methods comes from the way it is often linked to comparative studies of migration. FitzGerald (2012, p. 1728) calls this the ceteris paribus problem. In other words, one should not assume that an observed difference between two migration destinations causes the variation found between migration streams sharing the same source; or, analogously, that variations observed between different migration sources directed to the same destination derive from variations in the origins. In reality, the various sites (origins, destinations) are not isolated units each independent from the other: there may be prior links established through histories of colonisation, trade, or earlier waves of migration, as well as more recent forms of globalisation (de Munck 2002; Hansen 2014). That said, FitzGerald goes on to maintain that 'qualitative researchers are well positioned to make convincing claims about causal relevance when they are able to specify causal pathways and processes with detailed evidence from multiple sites' (2012, p. 1729).

The final critique to Marcusian multi-sited ethnography is what Falzon (2009, p. 12) calls the 'latter-day holism' charge. Multi-sited ethnography implies holistic ambitions, not least because of explicit reference to the 'world system' in the title of Marcus' 1995 paper. Whilst the capitalist world system, as envisioned for instance by Wallerstein (1979), provides a contextual structuring for people's lives and behaviours - including migration (cf. Castles and Miller 2009, pp. 26-27) - the suggestion is that the 'ethnographic macro-trope' (Rumsey 2004) of holism implies a higher level of comprehensiveness. Two answers are given by Falzon (2009, pp. 12-13) to this dilemma. The first is that holism is also and already built into the epistemology of the 'traditional' Malinowskian ethnographic monograph, designed to comprehend the workings of the 'social whole' of a designated community. The second is that multi-sited ethnography should not exaggerate its ambitions when trying to study 'everything'; it should opt instead for a 'limited slice of the action' such as, to give just one example, remittances. 


\subsubsection{Follow the People, and Other Things Too}

Marcus' powerful statement of justification for the intrinsic value of multi-sited research remains, however, rooted in the academic and epistemological traditions of anthropology and ethnography. I now turn this discussion more firmly towards the study of migration, and at the same time, broaden out from anthropology and ethnography to other social sciences that deal with this subject matter - sociology, geography, cultural studies, oral history, etc. Meantime, I stick with Marcus in his 'modes of construction', through which he suggests following 'the people', 'the thing', 'the metaphor', 'the story', 'the biography' and 'the conflict' (1995, pp. 105-110).

Follow the people is the most obvious link to migration, especially in studies which take a transnational approach or look at diasporic processes of 'scattering'. Following migrants across borders, to their sites of destination and settlement, is the classic genre of 'here' and 'there' research, but, of course, this is only one construction of the migration process. As noted already, contemporary European migration is much more complex and comprises, inter alia, onward migration, return migration, circulation, seasonal movements, internal migration, and the under-studied phenomenon of migrants visiting 'home' as well as being visited by their homebased relatives and friends. Some of this complexity is revealed in the Albanian case-studies at the end of this chapter.

Follow the thing involves the study of mobile material objects. Food, commodities, gifts and money are the most obvious linkages to the study of migration. Migrants take some of their material goods with them, and add to this by constructing in their destination setting a material world which reminds them of 'home', as well as stimulating a trade in 'ethnic goods' to sustain these customs (notably in food products). In the same vein returnees who resettle back 'home' often bring with them material goods - furniture, pictures, the architectural styles of their newbuild houses etc. - which remind them (and others) of their migrant life. Remittances are perhaps the most important element in the socio-economic study of migration's impact on the home society and economy, and these, too, can be most effectively studied at both ends of the 'remittance corridor' (King et al. 2011).

Follow the metaphor 'involves trying to trace the social correlates and groundings of associations that are most clearly alive in language use and print or visual media' (Marcus 1995, p. 108). So the 'thing' being traced here falls within the realm of discourse, ideas and symbols, mediated through a variety of official and informal communication channels, from official policy and propaganda to received wisdom, hearsay and gossip. For the study of migration, the relevant examples might include discourses and information (accurate or biased) about a 'better life' through migration, or migration as an essential 'rite of passage' to adulthood and status (for more on 'migration discourse' see Van Dijk 2018 in this volume).

Follow the plot, story or allegory: this is a "virtually untried mode of constructing multi-sited research' according to Marcus (1995, p. 109), but its potential is clear, especially with the growing interest in social memory, cultural studies and oral 
history. There are both 'grand narratives' and 'small stories' about migration which are, potentially, effectively investigated through multi-sited research, including that which references multiple historical sites and sources.

Follow the life or biography deepens and personalises the previous mode, and again Marcus notes that there is much unrealised potential in developing multi-sited research which follows the life-history and key events of individuals or groups of mobile people across space and through time. According to Marcus (1995, pp. 109110), this approach can reveal the juxtapositions both across space and time of places and events which otherwise remain obscured, either because they were previously hidden or unknown, or because they were embedded in systems and structures which distorted their true meaning. The challenge is to statistically and/or graphically represent these 'migration histories' in a way that demonstrates patterns which can be easily read or visualised. Carling's (2012) 'migration history charts' represent a very clear visual mapping of migrants' (and non-migrants') positionings and movements through space and time, including the intersecting trajectories of different generations and family members.

Finally, follow the conflict opens up interesting and highly relevant possibilities to study evolving migration conflicts such as refugee flows across borders. The dramaturgical unfolding of the recent and on-going Syrian refugee crisis, with its complex and shifting routes through Turkey, the Aegean Sea, the Western Balkans, and on through Central Europe to refugee settlement end-points in Germany and Sweden, is a clear illustration of this (see King and Collyer 2016).

\subsection{Context and Multi-sitedness in Albanian Migration Research}

I round off this chapter with some examples of multi-sited field research from Albania, the country whose remarkable story of migration I have been closely following for the past 20 or so years. I summarise the multi-sited research design and findings from three funded projects for which I was principal investigator.

Albania can be regarded as an excellent example of a research laboratory for the study of migration processes, for two main reasons (King 2005). First, Albania was a 'closed society', with emigration banned, for the 45 years between the end of World War II and the collapse of the communist regime in 1990-1991. Hence the migration waves that virtually exploded out of the country during the 1990s and have continued at a steadier pace since 2000 can be viewed against this unusual situation of a migration tabula rasa. Second, the scale of the migration has been, in a relative sense, larger than any other European country, with a 'stock' of Albanians now living abroad (mainly in Greece and Italy, but in recent years expanding to other European countries and North America too), equivalent to nearly half the current resident population of the country -1.4 million vs. 3 million (World Bank 2011, p. 54). 


\subsubsection{Project 1: Albanians in London and Back 'Home'}

The first project was a piece of research commissioned by Oxfam GB and the Fabian Society which investigated the causes and consequences of migration in a development context, as well as trying to destroy some of the myths about migration propagated by the UK media (King et al. 2003). The project represented Oxfam GB's first engagement with migration as a poverty-alleviating strategy, and deliberately chose a recently-arrived migrant group in the UK which had not been studied before and where there was no history of prior migration. The prime objective was to collect robust empirical data on the development-inducing effects of migration for the home country. One important extra component of the research was a gender dimension, especially in the field of remittances.

Unlike the 'village-outward' approach, which follows migrants from their place of origin to multiple destinations, this research design worked the other way around, starting with the destination and tracing back to key places of origin in Albania. We used personal contacts to snowball out to the Albanian migrant population in and around London and collected 26 in-depth interviews, some of which were recorded. Despite the fact that we were operating on 'home turf', it proved extremely difficult to access informants, due to their reluctance to be interviewed, their suspicion that we were linked to the Home Office or the police, and their own ambiguous status in Britain - most had arrived in the late 1990s via 'irregular' routes, including having been smuggled into the country in the back of trucks. Most interviewees were young men aged in their 20s and 30s, reflecting the age and gender dynamics of irregular migration from Albania. However, some came as young families or via family reunification, and the sample included interviews with seven young married women.

Based on these interviews and other UK-based contacts, we were able to identify two key regions of origin in Albania, linked by internal migration: the mountainous north of the country, a region of remote villages and small towns; and the peri-urban fringes of the capital Tirana, the site of much newly-built informal housing on land of unclear ownership. In these two regions, 46 interviews were carried out with families with migrants in the UK, including some interviews with returned migrants. These interviews in Albania proved easier to carry out, and most were conducted in an informal, relaxed atmosphere.

The triangulation of findings between these three locations - London, rural north Albania and the urbanising periphery of Tirana - enabled us to generate wellgrounded insights into several processes linked to migration and the support and (under)development of home-country communities and localities, including the gendered nature of these processes. The multi-sited perspective allowed the crossreferencing of research findings from each 'corner' of the triangle. Furthermore, we were able to understand the complex gendered interrelations between international migration, remittances, internal migration, population concentration and depopulation, and strategies for survival and personal/family progress. In synthesis, our results confirm the following. 
First and foremost, the patriarchal nature of Albanian society dictates that migration in the 1990s (somewhat less so today) was a 'male thing', and this applied to remittances too. The women interviewed in London told us how they were not 'allowed' to send remittances; and in the families receiving remittances in Albania (usually the parents of the male migrant abroad), it was 'the man' (the father, the head of the family, the patriarch) who decided how the money sent should be spent, sometimes in consultation with the son abroad (King et al. 2003, pp. 71-87).

Second, our multi-sited field evidence uncovered the complex and dynamic interrelationships between internal and international migration (King et al. 2003, pp. 68-71). The most consistent interlinkage from our data was that migration to the $\mathrm{UK}$, and the income and remittances derived therefrom, are often used to finance an internal migration of the residual family from rural north Albania to Tirana. When migrants return, or contemplate return, it is to this more dynamic pole of the Albanian economy, not to their depopulating places of origin in the hills and mountains. This finding is confirmed by Vullnetari's (2012) more comprehensive analysis of the internal-international migration interface in Albania, based on multi-sited fieldwork in three south Albanian villages and in Korçë (the local regional capital), Tirana and Thessaloniki.

Third, the impact of return migration and returnees' investment in the Albanian economy was found to be rather limited (King et al. 2003, pp. 87-92). Interviews in London and with migrant families and returned migrants in different locations in Albania revealed the barriers and challenges to a 'sustainable' return. On the whole, migrants left initially with the ambition to return (to get married, start a family, set up an enterprise, etc.), but the poor economic prospects in Albania, the lack of adequate infrastructure (reliable power and water supplies, decent roads, etc.), and the pervasive culture of bribery and corruption as well as, in some cases, longrunning inter-family feuds, were seen and experienced as fundamental obstacles. Nevertheless, some localised successes of returnees' investment in agriculture, tourism and small-scale service activities were encountered.

\subsubsection{Project 2: Regional Contrasts in Albanian Migrants' Social Inclusion in Italy}

The second project looked at Albanian migration to Italy and at the regionally differentiated process of social integration. The research was funded by the Leverhulme Trust and culminated in the book Out of Albania (King and Mai 2008). The aim of the research was to document, through detailed on-the-ground fieldwork, the process of Albanian migration to Italy, encompassing the migration itself, experiences of employment, housing and social life, and the way the migrants reacted to, and partially overcame, their profound stigmatisation by Italian media and society during the 1990s and early 2000s. 
Given the sharp regional contrasts in Italian economic and social geography, we strategically chose three contrasting cities to base the fieldwork in: Rome, the national capital, positioned in the centre of Italy; Lecce, a medium-sized city in the southern Puglia region; and Modena in the north, another medium-sized city and statistically the richest in Italy at the time. This multi-sited design was predicated on what we knew of the spatial dynamics of Albanian migration to Italy: a marked concentration in the south-eastern region of Puglia as the main arrival point into Italy, but a relatively poor region with high unemployment and limited opportunities for immigrants' longer-term economic progress; followed by subsequent northward migration within Italy, either to Rome with its multitude of mostly low-grade service employment, or to regions further north which have thriving industries (King and Mai 2008, pp. 6-8).

Given the time and resources available, we specified quota-sample targets of at least 30 in-depth interviews with Albanian migrants in each of the three cities, plus a further quota of at least 20 per city of key-interviews with employers and community leaders. All these quota-targets were achieved or exceeded, with a total of 174 interviews.

Key findings which vindicate this multi-sited research design are as follows. The main contrast uncovered was between the south of Italy (Lecce) and the north (Modena), with Rome occupying an intermediate position in terms of Albanians' experiences of social in/exclusion. In the south, Albanians found themselves, on the whole, more 'socially welcomed' and hence felt more 'at ease'; yet their material conditions, in terms of access to regular and decently-paid jobs, were much worse than in the north. For those whom we interviewed in and around Lecce, work opportunities were limited to casual and very poorly paid jobs in agriculture, or as temporary labourers on building sites or in storehouses. Qualifications earned in Albania - educational diplomas or vocational expertise - counted for nothing, so many experienced de-skilling in the work they did in Italy.

Many interviewees recalled their brutal experiences at the hands of the police at the time of the chaotic mass arrivals at the Puglian ports in 1991 when tens of thousands of Albanians arrived on overcrowded boats in a few days. Yet there were also some accounts of extraordinary help and kindness on the part of local people who virtually adopted young Albanians. Although the subsequent politically motivated and media-induced stigmatisation of Albanians covered all parts of the country, we found that, at an informal, neighbourhood level, Albanians were much better integrated in the south where, on the whole, they enjoyed good relationships with their Italian neighbours and workmates. We tentatively 'explained' this by the fact that southern Italians have their own personal and family experience of emigration: hence a sense of 'solidarity' is shared with the Albanian migrants.

In the north, and to a lesser extent in Rome, access to better-paid and somewhat more secure jobs was easier for Albanians, due to the demand for service-sector labour and (in Modena) some industrial jobs. Here, progress was easier once a migrant had been 'regularised' - and in fact it was difficult to survive in Modena without 'papers' (in contrast to the south where the police and authorities generally turned a blind eye). As a result, many Albanians moved internally from south to 
north within Italy once they got regularised, as this enabled them to access the formal labour market more prevalent in the north. The counterpoints to this better material and legal situation were twofold - a higher cost of accommodation (hence Albanians were often forced to locate to cheaper housing in outlying villages and small towns), and a less welcoming social environment, whereby they continued to be marginalised by the more class-conscious northern Italian bourgeoisie. This was particularly the case in the rich but provincial city of Modena; less so in multicultural Rome, where Albanians were only one of a vast array of recently-arrived and more established immigrant groups from all over the world.

\subsubsection{Project 3: Gendering the Greece-Albania Remittance Corridor}

For the final example, we return to one of the themes opened up by Project 1 and explore this in more detail. This is about gendering remittances along what we call 'the Greek-Albanian migration and remittance corridor', a project funded by UN-INSTRAW (United Nations Institute for Training and Research into the Advancement of Women) and UNDP (United Nations Development Programme): see King et al. (2011) and Vullnetari and King (2011) for key outputs.

The key questions which framed in this project were as follows. How do men and women within transnational families send and receive remittances? To what extent, therefore, is the transmission and use of remittances imbued with relations of patriarchy between genders and generations? Thirdly comes the recursive question of the previous one: how does the earning, transmission and decision-making over remittances re-shape gender relations within transnational families (if at all)? Finally, how are remittances used - for survival, for consumption, or for investment for the future?

The research plan for this project was both multi-method and multi-sited - a common combination in the field of migration research. The multi-sited design was linked to the above-mentioned concept of a migration and remittance corridor - a linear channel between two countries, regions or localities along which migrants move in one direction (typically from the 'poor' to the 'rich' region) in order to work and send a portion of their earnings home to family members in the form of remittances. These are usually mainly in monetary form but can also include goods and gifts. The precise sites where the research was carried out were a cluster of three villages in the district of Korçë, southern Albania, and the city of Thessaloniki in northern Greece, the main destination for migrants from this part of Albania. This is a rather short-range, cross-border migration-remittance corridor, compared to other globe-spanning examples (US-Mexico, Spain-Ecuador, Gulf-South Asia, etc.). Buses, taxis and private cars make the journey in 3-4 h, except when there are long queues at the border. This vehicular traffic is also used to deliver in-kind remittances in the form of parcels. 
The mixed-methods package involved three main research instruments: a faceto-face household questionnaire survey of 350 remittance receivers in the Albanian villages; in-depth recorded interviews with 25 remittance receivers in the three villages and with 20 remittance senders in Thessaloniki; and some flexibly organised discussion/focus groups with village women.

Key results include the following. The questionnaire data allowed a rigorous mapping and categorisation of 'remittance dyads' - person-to-person transfers between a sender and a recipient, identified by gender, generation or other consanguinal relationship. Dyads were found to be highly gender-specific (Vullnetari and King 2011, pp. 113-123). Single male migrants send to their fathers. Married male migrants working abroad alone send mainly to their wives, except when their wives are cohabiting with the migrant's parents, in which case the remittances go to the father. In cases where the migrant is together with his wife abroad, the remittances go to his father, even when the migrant's wife is working abroad, since she is deemed to 'belong' to her husband's parental family, not her own, according to the Albanian patrilineal system. However, our interview evidence revealed that this rigid pattern is changing somewhat, and some remittances are sent to the wife's parents, especially if they are in need, for example if they have no sons working abroad to support them, and hence no incoming remittances of their own.

Hardly any females are 'primary' remitters: only 4 out of the 350 recipient households had migrant women as their main remitters. Married migrant women were sometimes 'allowed' to send money and gifts to her parents (or occasionally a sister), but, revealingly, these are re-labelled 'gifts' or small monetary 'presents' ('just for a coffee') and hence downgraded in significance.

Whilst there was no doubt, based on questionnaire responses, that patriarchal principles remain intact, especially as regards the denied independence of women as 'sole' migrants or active remitters, evidence from in-depth interviews revealed that the experiences of migration on the one hand, and of receiving and administering remittances on the other hand, were reshaping gender relations. In migrant households in Thessaloniki, husbands were sharing in household chores and in looking after children. This was not so much because of a profound ideological shift in the norms of gender equality, but more because of the necessities of two working spouses with different shifts. For migrant working women in Thessaloniki, freedom to travel around the city (again, out of necessity, to get to work or ferry children to school and other events), and to retain some control over money, could be regarded as modest means of empowerment. The same could be said of women as recipients and administrators of remittances; on the other hand, some women 'left behind' by husbands working abroad felt over-burdened by all the responsibilities being thrust on them - to look after children and perhaps also elderly parents(-in-law), to work on the household land and look after the animals, and manage the household economy on a daily basis.

Finally, this research uncovered differences and even clashes in expectations about the amount, frequency and utilisation of remittances - inconsistencies which can only emerge from the different perspectives of a two-ended, multi-sited and multi-method investigation, interrogating both the senders and receivers of remittances. 


\subsection{Conclusion}

The diversity, complexity and dynamism of migration as a multi-faceted social, economic and cultural process requires the researcher to have a broad and interdisciplinary vision, as Borkert (2018) expounds in the next chapter. The breadth of this vision reflects not only the complex internal dynamics of migration but also the way that migration is embedded in regional and global processes, such as evolving geographies of uneven development and global geopolitical change. Migratory phenomena are also emplaced - in places of origin, destination, transit and return. Migrations are channelled along routes and networks, and interrupted and diverted by borders. To quote the evocative title of one paper which argues strongly for a multi-sited ethnographic approach, migrants move 'inside, outside, upside down, backward, forward, round and round' (McHugh 2000). Despite its restricted spatial scale, the 'Albanian laboratory' for studying migration dynamics as they unfold in time and space offers an excellent illustration of the value of multi-method and multi-sited research which surely can be paralleled in many other geographical contexts within Europe and beyond.

\section{References}

Amelina, A., \& Faist, T. (2012). De-nationalizing the national in research methodologies: Key concepts in transnational studies in migration. Ethnic and Racial Studies, 35(10), 1707-1724.

Amelina, A., Faist, T., Glick Schiller, N., \& Nergiz, D. D. (2012). Methodological predicaments of cross-border studies. In A. Amelina, D. D. Nergiz, T. Faist, \& N. Glick Schiller (Eds.), Beyond methodological nationalism: Research methodologies for cross-border studies (pp. 1-19). New York: Routledge.

Anthias, F. (2009). Translocational belonging, identity and generation: Questions and problems in migration and ethnic studies. Finnish Journal of Ethnicity and Migration, 4(1), 6-15.

Baily, S. (1992). The village outward approach to the study of social networks: A case study of the Agnonesi diaspora abroad, 1885-1989. Studi Emigrazione, 29(105), 43-67.

Boccagni, P., \& Schrooten, M. (2018). Participant observation in migration studies: An overview and some emerging issues. In R. Zapata Barrero \& E. Yalaz (Eds.), Qualitative research in European migration studies (pp. $\mathrm{xx}-\mathrm{Xx}$ ). Cham: SpringerOpen.

Boissevain, J. (1980). A village in Malta. New York: Holt, Reinhart and Winston.

Borkert, M. (2018). Moving out of the comfort zone: Promises and pitfalls of interdisciplinary migration research in Europe. In R. Zapata Barrero \& E. Yalaz (Eds.), Qualitative research in European migration studies (pp. $\mathrm{xx}-\mathrm{xx}$ ). Cham: SpringerOpen.

Brettell, C. B., \& Hollifield, J. F. (Eds.). (2015). Migration theory: Talking across disciplines (3rd ed.). New York: Routledge.

Brickell, K., \& Datta, A. (Eds.). (2011). Translocal geographies: Space, place and community. Farnham: Ashgate.

Burawoy, M. (2003). Revisits: An outline of reflexive ethnography. American Sociological Review, 68(5), 645-679.

Büscher, M., Urry, J., \& Witchger, K. (2010). Mobile methods. Abingdon: Routledge.

Büschet, M., \& Urry, J. (2009). Mobile methods and the empirical. European Journal of Social Theory, 12(1), 99-116. 
Candea, M. (2007). Arbitrary locations: In defence of the bounded field-site. Journal of the Royal Anthropological Institute, 13(1), 167-184.

Carling, J. (2012). Collecting, analysing and presenting migration histories. In C. Vargas-Silva (Ed.), Handbook of research methods in migration (pp. 137-162). Cheltenham: Edward Elgar.

Castles, S., \& Miller, M. J. (2009). The age of migration: International population movements in the modern world (4th ed.). Basingstoke: Palgrave Macmillan.

Clifford, J. (1997). Routes: Travel and translation in the late twentieth century. Cambridge, MA: Harvard University Press.

Coleman, S., \& von Hellermann, P. (2011). Introduction: Queries, collaborations, calibrations. In S. Coleman \& P. von Hellermann (Eds.), Multi-sited ethnography (pp. 1-15). New York: Routledge.

Cresswell, T. (2006). On the move: Mobility in the modern western world. London: Routledge.

Crul, M., Schneider, J., \& Lelie, F. (Eds.). (2012). The European second generation compared: Does the integration context matter? Amsterdam: Amsterdam University Press.

Cwerner, S. (2001). The times of migration. Journal of Ethnic and Migration Studies, 27(1), 7-36.

De Munck, V. C. (2002). Contemporary issues and challenges for comparativists: An appraisal. Anthropological Theory, 2(1), 5-19.

Faist, T. (2000). The volume and dynamics of international migration and transnational social spaces. Oxford: Clarendon Press.

Falzon, M.-A. (2005). Cosmopolitan connections: The Sindhi diaspora, 1860-2000. New Delhi: Oxford University Press.

Falzon, M.-A. (2009). Introduction: Multi-sited ethnography: Theory, praxis and locality in contemporary research. In M.-A. Falzon (Ed.), Multi-sited ethnography: Theory, praxis and locality in contemporary research (pp. 1-23). Farnham: Ashgate.

Fielding, A. (1993). Mass migration and economic restructuring. In R. King (Ed.), Mass migration in Europe: The legacy and the future (pp. 7-18). London: Belhaven Press.

FitzGerald, D. (2012). A comparativist manifesto for international migration studies. Ethnic and Racial Studies, 35(10), 1707-1724.

Foner, N. (1997). What's new about transnationalism? New York immigrants today and at the turn of the century. Diaspora, 6(3), 355-376.

Fröbel, F., Heinrichs, J., \& Kreye, O. (1980). The new international division of labour. Cambridge: Cambridge University Press.

Geertz, C. (1973). The interpretation of cultures. New York: Basic Books.

Glick Schiller, N., \& Çaglar, A. (2009). Towards a comparative theory of locality in migration studies: Migrant incorporation and city scale. Journal of Ethnic and Migration Studies, 35(2), 177-202.

Glick Schiller, N., Basch, L., \& Blanc-Szanton, C. (1992). Towards a transnational perspective on migration. Annals of the New York Academy of Sciences, 645, 1-24.

Hage, G. (2005). A not so multi-sited ethnography of a not so imagined community. Anthropological Theory, 5(4), 463-475.

Hansen, T. B. (2014). Migration, religion and post-imperial formations. Global Networks, 14(3), 273-290.

Hoerder, D. (2012). Transnational - transregional - translocal: Transcultural. In C. Vargas-Silva (Ed.), Handbook of research methods in migration (pp. 69-91). Cheltenham: Edward Elgar.

Iosifides, T. (2018). Epistemological issues in qualitative migration research: Self-reflexivity, objectivity and subjectivity. In R. Zapata Barrero \& E. Yalaz (Eds.), Qualitative research in European migration studies (pp. $\mathrm{xx}-\mathrm{xx}$ ). Cham: SpringerOpen.

Jacobs, D. (2018). Categorising what we study and what we analyse, and the exercise of interpretation. In R. Zapata Barrero \& E. Yalaz (Eds), Qualitative research in European migration studies (pp. $\mathrm{xx}-\mathrm{xx}$ ). Cham: SpringerOpen.

Khagram, S., \& Levitt, P. (Eds.). (2008). The transnational studies reader: Interdisciplinary intersections and innovations. New York: Routledge.

King, R. (1985). The industrial geography of Italy. London: Croom Helm. 
King, R. (Ed.). (1993). Mass migration in Europe: The legacy and the future. London: Belhaven Press.

King, R. (2005). Albania as a laboratory for the study of migration and development. Journal of Southern Europe and the Balkans, 7(2), 133-155.

King, R., \& Collyer, M. (Eds.). (2016). Geographical perspectives on the 'European Migration and Refugee Crisis'. Human Geography, 9(2), 1-112.

King, R., \& Lulle, A. (2015). Rhythmic island: Latvian migrants and their enfolded patterns of space-time mobility. Population, Space and Place, 21(7), 599-611.

King, R., \& Mai, N. (2008). Out of Albania: From crisis migration to social inclusion in Italy. New York/Oxford: Berghahn.

King, R., \& Skeldon, R. (2010). 'Mind the gap!' Integrating approaches to internal and international migration. Journal of Ethnic and Migration Studies, 36(10), 1619-1646.

King, R., Mai, N., \& Dalipaj, M. (2003). Exploding the migration myths. London/Oxford: Fabian Society and Oxfam GB.

King, R., Castaldo, A., \& Vullnetari, J. (2011). Gendered relations and filial duties along the Greece-Albania remittance corridor. Economic Geography, 87(4), 393-419.

Levitt, P., \& Glick Schiller, N. (2004). Transnational perspectives on migration: Conceptualizing simultaneity. International Migration Review, 38(3), 1002-1040.

Marcus, G. E. (1995). Ethnography in/of the world system: The emergence of multi-sited ethnography. Annual Review of Anthropology, 24, 95-117.

Marcus, G. E. (2007). How short can fieldwork be? Social Anthropology, 15(3), 353-367.

Marcus, G. E. (2011). Multi-sited ethnography: Five or six things I know about it now. In S. Coleman \& P. von Hellermann (Eds.), Multi-sited ethnography (pp. 16-32). New York: Routledge.

McHugh, K. (2000). Inside, outside, upside down, backward, forward, round and round: A case for ethnographic studies in migration. Progress in Human Geography, 24(1), 71-89.

Meeus, B. (2012). How to catch floating populations? Research and the fixing of migration in space and time. Ethnic and Racial Studies, 35(10), 1775-1793.

Nader, L. (1969). Up the anthropologist - perspectives gained from studying up. In D. Hymes (Ed.), Reinventing anthropology (pp. 284-311). New York: Pantheon.

Penninx, R., Berger, M., \& Kraal, K. (Eds.). (2006). The dynamics of international migration and settlement in Europe: A state of the art. Amsterdam: Amsterdam University Press.

Pratsinakis, M., Hatziprokopiou, P., \& King, R. (2017). Beyond migration binaries and linear transitions: The complexification of Greece's migratory landscape at times of crisis (Working Paper 92). Brighton: University of Sussex, Sussex Centre for Migration Research.

Rumsey, A. (2004). Ethnographic macro-tropes and anthropological theory. Anthropological Theory, 4(3), 267-298.

Sklair, L. (2001). The transnational capitalist class. Oxford: Blackwell.

Smith, R. C. (2006). Mexican New York: The transnational lives of new immigrants. Berkeley: University of California Press.

Urry, J. (2007). Mobilities. Cambridge: Polity.

Van Dijk, T. (2018). Discourse and migration. In R. Zapata Barrero \& E. Yalaz (Eds.), Qualitative research in European migration studies (pp. $\mathrm{xx}-\mathrm{xx}$ ). Cham: SpringerOpen.

Vathi, Z. (2015). Migrating and settling in a mobile world: Albanian migrants and their children in Europe. Cham: Springer.

Vullnetari, J. (2012). Albania on the move: Links between internal and international migration. Amsterdam: Amsterdam University Press.

Vullnetari, J., \& King, R. (2011). Remittances, gender and development: Albania's society and economy in transition. London: I.B. Tauris.

Waldinger, R., \& FitzGerald, D. (2004). Transnationalism in question. American Journal of Sociology, 109(5), 1177-1195.

Wallerstein, I. (1979). The capitalist world-economy. Cambridge: Cambridge University Press. 
Watson, J. L. (Ed.). (1977). Between two cultures: Migrants and minorities in Britain. Oxford: Blackwell.

Wimmer, A., \& Glick Schiller, N. (2002). Methodological nationalism and beyond: Nation-state building, migration, and the social sciences. Global Networks, 2(4), 301-314.

World Bank. (2011). Migration and remittances factbook 2011. Washington, DC: World Bank.

Zapata Barrero, R., \& Yalaz, E. (2018). Introduction: Preparing the Way for Qualitative Research in Migration Studies. In R. Zapata Barrero \& E. Yalaz (Eds.), Qualitative research in European migration studies (pp. $\mathrm{xx}-\mathrm{Xx}$ ). Cham: SpringerOpen.

Open Access This chapter is licensed under the terms of the Creative Commons Attribution 4.0 International License (http://creativecommons.org/licenses/by/4.0/), which permits use, sharing, adaptation, distribution and reproduction in any medium or format, as long as you give appropriate credit to the original author(s) and the source, provide a link to the Creative Commons license and indicate if changes were made.

The images or other third party material in this chapter are included in the chapter's Creative Commons license, unless indicated otherwise in a credit line to the material. If material is not included in the chapter's Creative Commons license and your intended use is not permitted by statutory regulation or exceeds the permitted use, you will need to obtain permission directly from the copyright holder.

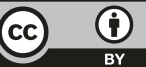

